\title{
The Social Construction of Young People within Education Policy: evidence from the UK's Coalition Government
}

\section{Rachel Brooks, University of Surrey.}

\begin{abstract}
Since assuming power in May 2010, the UK’s Coalition government has devoted considerable energy to formulating its policies with respect to young people. Evidence of this can be found in Positive for Youth: a new approach to cross-government policy for young people aged 13-19, a policy text that outlines a wide range of measures to be implemented across nine government departments. Nevertheless, we know little about the understandings of young people that underpin Coalition policy or the political ideology that informs them. This paper starts to redress this gap by exploring the ways in which young people have been constructed within education policy, specifically, and the extent to which such constructions constitute continuity or change with the understandings of previous governments. It argues that while some constructions of young people can be seen primarily as an extension of New Labour understandings, other constructions should be more accurately viewed as reconfigurations or, in some cases, as new understandings, initiated by the Coalition government.
\end{abstract}

\section{Introduction}

Since assuming power in May 2010, the UK’s Coalition government has devoted considerable energy to formulating its policies with respect to young people. Evidence of this can be found in Positive for Youth: a new approach to cross-government policy for young 
people aged 13-19 (DfE, 2011), a policy document that outlines a wide range of measures to be implemented across nine government departments. Nevertheless, to date, we know little about the understandings of young people that underpin Coalition policy or the political ideology that informs them ${ }^{\mathrm{i}}$. This paper starts to redress this gap by exploring the ways in which young people have been constructed within education policy, specifically, and the extent to which such constructions constitute continuity or change with the understandings of previous governments. First, however, to provide some background to the policy analysis, it gives a brief overview of extant literature of the political make-up of the Coalition government.

\section{The political ideology of the Coalition government}

The UK general election of 2010 was the first since 1974 to produce a hung parliament and resulted in the first peacetime coalition government since the 1930s. This coalition was between the centre-right Conservatives, who had gained 306 of the 650 available seats at the election, and the centre-left Liberal Democrats, who had gained 57 - and, to many, the two parties appeared to have little in common (Evans, 2011). Analyses of the Coalition Agreement, which was negotiated by the parties in May 2010, differ in their assessment of the winners and losers in this document. Quinn et al. (2011) contend that both the Conservatives and Liberal Democrats secured considerable gains on their policy priorities: the Liberal Democrats through the overall positioning of the agreement on the left-right spectrum, and the Conservatives in a number of specific policy areas. In contrast, Evans (2011) suggests that, during the coalition negotiations, the Conservatives made relatively few concessions to the Liberal Democrats and gained significantly more from the arrangement than did their junior partner. 
Within the academic literature published to date, there is also little consensus about the ideological underpinnings of the Coalition government as evidenced by its actions since taking up office. In some particular areas, continuity with New Labour seems strong. For example, in her analysis of welfare reform and, in particular, the approach to those with disabilities, Garthwaite (2011) suggests that policy has remained focussed on the supply, rather than the demand, side of labour and, in common with previous governments, has done little to address the social inequalities of work. Similarly, in their discussion of health policy, Pollock and Price (2011) maintain that the Coalition's drive towards further marketisation can be seen as part of a trajectory which has characterised government policy from the 1990s onwards under both Conservative and Labour administrations.

Others have, however, argued that in some areas of social policy clear discontinuities with the previous administration are evident. Firstly, it has been suggested that the significant cuts to public expenditure made by the Coalition represent, not merely an attempt to reduce the national debt, but a more profound restructuring of the public sector:

The objective is to set the UK on a trajectory of permanently lower spending, lower debt and market-led growth. Future pressures on the state will be contained through a shift in responsibility in many areas from state to private providers, citizens or the community. Market principles will permeate social life to a greater extent than at any time since the inception of the welfare state. (Taylor-Gooby, 2012, p.62)

Secondly, some commentators have argued that the Coalition's commitment to decentralisation and localism distinguishes it from previous administrations. Indeed, 
Lowndes and Pratchett (2012) maintain that the reforms introduced by the Coalition during its first year in office show 'traces of an ideological commitment to localism and a new understanding of local government’ (p.22), and go on to argue that the Coalition’s ideological agenda 'has the power to deliver a radically different form of local government' (ibid.). However, they also point out some of the practical constraints which may impede implementation of a radical agenda. Similarly, Painter (2012) suggests that while decentralisation (along with openness and transparency) constitutes an important part of the Coalition's welfare narrative - and is often used by Conservatives and Liberal Democrats to distinguish their public service reform programme from what they describe as the 'top-down configuration of power' (p.2) under New Labour - in practice, the differences have not been so marked. Painter (ibid.) argues that education policy is a good example of this: while autonomy and decentralisation have provided much of the underpinning rationale for the Coalition’s flagship ‘free schools' ${ }^{\text {ii }}$ policy, 'financial incentives for a rapid acceleration in the number of schools converting to academy status ${ }^{\mathrm{iii}}$ created a potentially centralizing dynamic, by undermining local education authorities and placing such ostensibly autonomous state schools within the orbit of the Department for Education’ (p.5). Finally, some feminist scholars have argued that Coalition social policy is predicated on a more regressive understanding of gender relations than that of the previous government. MacLeavy (2011) contends that as women as a group are particularly reliant on benefits and tax credits as social protection, they are likely to be more adversely affected than men when they are cut back through the Coalition's austerity measures. She goes on to suggest that, by failing to take account of these links between economic redistribution and gender inequality, the government risks further embedding and exacerbating this linkage. Moreover, others have argued that as women are likely to be the ones to fill gaps (largely in care-giving) where public services have been cut, 'it seems that the Coalition is happy to restore an outdated 
“male breadwinner, dependent female carer” model of family life that neither fits with women’s aspirations nor today’s financial necessities’ (Annesley and Himmelweit, 2010, p.2).

These themes provide the context for the analysis of constructions of young people within education policy that follows, and are returned to, explicitly, in the final section of the paper.

\section{Policy documents}

Over its first two years in power, the UK Coalition government published a wide range of policy texts that address different aspects of education and training. However, most of its key policies that impact on the lives of young people are contained in Positive for Youth: a new approach to cross-government policy for young people aged 13-19 (DfE, 2011) published in 2011. This is a lengthy text (98 pages) which, as noted previously, brings together policies from nine different government departments. It thus constitutes a central source for this article. Two other key texts were also analysed: the schools white paper, The Importance of Teaching (DfE, 2010), which was published within six months of the Coalition government taking office, and the higher education white paper, Higher Education: Students at the Heart of the System (BIS, 2011), published in June 2011. Together, these three documents provide a detailed overview of current Coalition policies with respect to the role of education in the lives of young people.

An inductive, thematic analysis was conducted on these three documents, exploring the way in which young people were being represented, and the conceptualisations of youth that underpinned the various policy measures. First, the documents were coded - using codes 
derived from the documents themselves, but which were also, in some cases, informed by reading of the extant literature in youth studies, education and related fields. Second, the coded material was used to identify dominant themes across the dataset. Finally, my initial interpretation was presented to colleagues (in a workshop setting) to gain feedback on the validity and reliability of my analysis, and some modifications were made subsequently, as a result. An important aspect of the analysis was to assess the extent to which the constructions evident in Coalition discourse represented continuity or change with the dominant constructions of young people under the previous administration (the New Labour government, 1997-2010) ${ }^{\mathrm{iv}}$. Here, comparisons were drawn with the understandings of young people which underpinned key Labour policies with respect to young people and education (e.g. DfES, 2003; DfES, 2005a; DfES, 2005b; DfES, 2005c).

The remainder of this article considers six dominant constructions that emerged from the analysis of Coalition documents and, for each, explores the extent to which it represents continuity with New Labour policy. These constructions of young people are as: friends and students of business; active consumers; dutiful citizens; the children of authoritative parents; 'good characters-in-the-making'; and a unitary group. The article argues that while some of these can be seen primarily as an extension of New Labour understandings, others should be more accurately viewed as reconfigurations of New Labour policy or, in some cases, as more distinct understandings, initiated by the Coalition government.

\section{Dominant constructions of young people in Coalition documents}

Friends and students of business 
In his analysis of the changing nature of UK education over the past two decades, Ball (2007) contends that the traditional emphasis on the moral obligations of teaching and learning have been lost; instead, education has come to be seen primarily in terms of its economic value and contribution to competitiveness within international markets. Associated with this shift in values has been a change in the role of the state: a primary focus on public sector provision of services has been replaced with an emphasis on monitoring and contracting externallyprovided services, and stimulating competition. As a result, the private sector has become 'embedded in the heart and sinews of state education services at all levels' (p.41), including 'the day-to-day business of decision making, infrastructural development, capacity building and service delivery’ (ibid.). Ball argues that the increasing involvement of the private sector is not merely a technical change in service delivery, but has had a profound influence on our lives more generally - effecting our relationships with one another and also how we think about ourselves.

Part of this reconstitution of identity can be seen in the construction of young people, within policy texts from the New Labour period (and also from earlier), as both friends and students of business. Indeed, the increasing involvement of the private sector within schools and universities has often been predicated on the assumption, firstly, that the interests of students are broadly in line with those of business and, secondly, that young people can only benefit from adopting business values, such as enterprise, entrepreneurship and competitive individualism. Under New Labour, this is evident in relation to both compulsory and postcompulsory education. Within the former, the sharing of staff 'between schools, colleges and business' (DfES, 2005b, p.98) was encouraged while, for 14-19 year olds, an 'Enterprise Education Initiative' was launched, to underscore 'the importance of financial capability as a context for, and key underpinning of, enterprise capability, along with economic and business 
understanding' (DfES, 2005a, p.40). Similar themes were rehearsed with respect to higher education, with the 2003 white paper arguing that, 'In a knowledge-based economy both our economic competitiveness and improvements in our quality of life depend on the effectiveness of knowledge sharing between business and higher education' (DfES, 2003, p.36). More explicitly, it suggested that:

Universities have a role in fostering the establishment and growth of new companies; in working with existing companies both on the application of the latest technology and the successful application of more tried and tested technologies; and in working with business to develop the skills of the workforce at technical and professional levels. At their best, these links should be highly interactive, with each partner well aware of what the other can offer, and of what their needs are. (ibid., p.37)

Such assumptions show strong continuity within Coalition education policy. Indeed, there are numerous examples of initiatives to bring education and business closer together throughout Positive for Youth. One example is the plan to develop 'Studio Schools' for 14-19 year olds. In such schools, pupils will study 'a broad and balanced curriculum designed to give them the skills they will need in work' (DfE, 2011, p.26). In addition, a significant portion of the week will be spent working for a local employer (16-19 year-olds will be paid for this; 14 and 15 year-olds will not). It is intended that pupils at such schools will work a 9am-5pm day to model real-life working conditions and, instead of having set terms and holidays, they will have to apply for annual leave. Moreover, closer involvement with the world of work is advocated for all pupils. Indeed, Positive for Youth suggests that work experience should become an important part of the school or college experience of all 16-18 year olds, not just their younger peers, as has typically been the case in English schools. It is claimed that such 
experience 'will open up new horizons for young people of every ability and background. It will raise their career aspirations and help them develop a wide range of skills, from team working to problem solving, and improve their work-readiness' (p.30). Here, the world of work is presented as emancipatory - by being able to raise the aspirations of young people from all backgrounds - and implicitly contrasted with an education system which, to date, has not been able to effect such change. Business involvement is also seen as central to reforms to higher education. Students at the Heart of the System (BIS, 2011), the higher education white paper, calls upon all universities to: 'look again at how they work with business, across their teaching and research activities, to promote better teaching, employer sponsorship, innovation and enterprise' (p.39).

As with the schools sector, business is seen as fundamental to both the purpose and practice of education. Positive for Youth goes beyond this, however, suggesting that individual dispositions have to be realigned in accordance with business values. As will be discussed in more depth below, being both 'enterprising and entrepreneurial' (p.37) is seen as a necessary component of the 'good character' of the ideal Coalition subject.

\section{Active consumers}

Coalition policy also shows clear continuity with previous administrations in its construction of young people as active consumers within educational markets. Indeed, for the past two and half decades, 'educational choice’ (by prospective students and their families) has been seen by many policymakers from across the political spectrum as a key mechanism for promoting competition between institutions and, as a consequence, for raising standards (Ball, 2003; Foskett and Hemsley-Brown, 2001). Under New Labour, this was evident across the 
educational spectrum. Within higher education, policymakers believed that there was a strong correlation between degree of student choice and quality of education received:

The Government believes that student choice will be an increasingly important driver of teaching quality, as students choose the good-quality courses that will bring them respected and valuable qualifications and give them the higher-level skills that they will need during their working life. (DfES, 2003, p.47)

Similarly, New Labour committed itself to expanding consumer 'choice' in earlier stages of education, in the belief that it would offer an effective means of improving the schools sector as a whole:

Parent choice can be a powerful driver of improved standards. Performance tables and inspections have given many parents the information that has enabled them to make objective judgements about a school's performance and effectiveness. This has been an important pressure on weaker schools to improve. (DfES, 2005b, p.3)

To respond to parental demand, we need to expand choice, create real diversity of provision, and to ensure that the benefits of choice are available to all. (DfES, 2005b, p.20)

Young people's construction as active consumers is evident not only in policy texts; they have also been viewed in a similar way by the media which, on the whole, has tended to welcome this identity shift, in the belief that active consumers are more likely to be able to hold educational institutions to account (Williams, 2011). 
This consumerist model is endorsed and extended by Coalition policy - within both the school and university sectors. This is to be effected by, firstly, widening the variety of educational establishments that 'consumers' can choose between. Indeed, Positive for Youth notes that 'The Government recognises the need for further innovation in the schools system to increase choice for parents and students’ (p.25). Secondly, and particularly in the higher education sector, more information is to be provided, to enable prospective students to 'become more discerning' choosers (BIS, 2011, p.29). Students at the Heart of the System explains how universities will be required to make available a 'Key Information Set' for each course to facilitate greater choice on the part of the student. This will include information about: the course itself (comprising student satisfaction ratings, the proportion of time spent in different teaching and learning activities, the methods of assessment used, and details of any professional bodies that recognise the course); the costs (for accommodation and tuition) and available sources of student support; the employment of graduates from the course (destinations, proportion in a full-time 'graduate' job six months after graduation, and average salaries); and graduates' views of the impact of their institution's students' union. Universities will also have to produce student charters which will set out the mutual expectations of students and the institutions they attend.

New Labour policies on ‘educational choice’ were criticised on a number of grounds but, particularly, for assuming that all social groups were equally inclined and able to 'choose' within educational markets. Research has suggested, for example, that middle-class families are far more likely to exercise choice (through the acquisition and consumption of information on the relative merits of different schools and universities as well as the complex mechanisms of school selection) than are their working-class counterparts (Ball, 2003). They 
are also far more likely to approach education strategically, reflecting the desire for valuable cultural capital (Brown, 1990) - findings that have also emerged from other Anglophone countries, which have adopted largely market-based education policies (Chubb and Moe, 1997; Lauder and Hughes, 1999). Even amongst those who are inclined to 'choose', social factors tend to restrict the choices available in significant ways. In their work in Greater London, Ball et al. (1997) identified three main circuits of school (local community comprehensive schools; cosmopolitan elite maintained schools; and local independent schools) and argued that different class fractions tend to choose within one circuit only. Similar arguments have been made in relation to the higher education sector. On the basis of their data on students’ choices, Reay et al. (2005) maintain that while privately educated students identified primarily with elite universities such as Oxford and Cambridge, middle class state-educated students had a strong preference for redbrick institutions founded prior to 1992, and those from working class backgrounds felt most at home in the newer universities (i.e. former polytechnics, many of which were granted university status in 1992).

While it seems likely that social factors will continue to mediate the choices made by prospective students, further limitations on the extent of consumer choice are also imposed by the nature of the market itself. For example, within the higher education sector, although there are no restrictions on the number of students with $A$ Level grades of $\mathrm{ABB}^{\mathrm{v}}$ an institution can recruit, the number of places for those with lower grades is capped (BIS, 2011). This suggests that the nature and extent of consumer choice is likely to be socially differentiated: while those with high grades are likely to be vigorously pursued by a large number of universities, those with grades below the ABB threshold are likely to face considerable competition for the (limited number of) available places. 


\section{Dutiful citizens}

The ideal Coalition young person is constructed by the policy documents as a 'dutiful citizen'. Such citizens are to be developed in two main ways: through strong encouragement of volunteering and the establishment of a National Citizen Service. Positive for Youth indicates that dedicated funding will be made available to volunteering charities (for example, to 'v', the national youth volunteering charity, the Youth Sport Trust and YouthNet, which runs a volunteering website) to provide more opportunities for young people to volunteer in their local communities. This emphasis on voluntary action is also an important component of the National Citizen Service. As outlined in Positive for Youth, this will offer a programme of personal and social development and volunteering activity for young people in the summer following the end of their compulsory schooling (at the age of 16). The government will provide funding to enable young people to spend two weeks away from home pursuing outward bound and voluntary activities; participants will then be expected to spend an additional 30 hours engaged in voluntary activity for their local community on their return home. Both initiatives are aimed at furthering young people's own development and inculcating 'the skills needed to be active, responsible citizens... [able to] make a difference in their communities together' (DfE, 2011, p.41). They are also argued to be effective means of ‘engaging the most disaffected’ (ibid., p.39).

The Coalition's focus on developing young people as citizens is not new. Under the previous Labour government, citizenship education was introduced in 2002 as a statutory part of the National Curriculum in England, comprising strands on political literacy, social and moral responsibility, and community involvement. While this initiative was welcomed by many educationalists, it was not without its critics. Indeed, Coffey (2004) argued that, under New 
Labour, practice tended to mask 'a contradiction in the discourses of citizenship - whereby citizenship can be perceived as part of a system of social control, or as a recognition of rights and social inclusion' (p.56). She went on to suggest that the Labour citizenship curriculum focused on the skills and competencies necessary to make a contribution to the economy and the realignment of concepts of social and moral understanding, rather than more innovative and democratic understandings of citizenship. This is a theme that has been pursued by others who have contended that the particular emphasis that was placed on community involvement within citizenship education (and also within policies to promote youth volunteering that were introduced by Labour (see DfES, 2005c, for details)) had the effect of undermining a Marshallian form of social citizenship (with emphasis on an individual's rights as well as his or her responsibilities), promoting, instead, an emphasis on voluntarism (Brooks, 2007, 2009; Hall and Williamson, 1999; Garmarnikow and Green, 2000). Longitudinal data collected by Lister and colleagues (2005) certainly suggests that young people’s views underwent a significant shift during this period. They note that, over the three years of their research, understandings of citizenship that emphasised universal status, people's right to a voice and a social contract became less common, while those that were based on economic respectability and social participation became more prevalent.

It seems likely that such trends may become exacerbated under the current Coalition government. It is widely believed that citizenship education will be dropped as a compulsory component of the National Curriculum following the review of the curriculum that is currently taking place and the Secretary of State for Education's widely espoused view that the number of compulsory subjects within the National Curriculum should be reduced (Shepherd, 2011). If this is the case, then the messages about citizenship given to young people are likely to become even more limited. While citizenship education, under New 
Labour, was criticised for promoting community involvement and responsibilities to others to the exclusion of a rights-based discourse, it did at least have a strand dedicated to political literacy. Without this, it seems likely that constructions of young citizens as 'dutiful' (rather than as critical and questioning) will become even more dominant.

\section{Children of authoritative parents}

The Coalition government can also be seen to be refiguring previous government constructions of young people in relation to its foregrounding of the importance of parents and parenting. Throughout Positive for Youth, parents are argued to be a key influence on the lives of young people. Indeed, it states that 'parenting has a greater impact on...wellbeing, learning and development than anything else' (p.19). Young people are thus represented as in

need of parenting, while parents themselves are represented as in need of support, advice and education:

\footnotetext{
Many parents...find it harder to cope during these [teenage] years and say they would welcome some additional advice and assistance. (DfE, 2011, p.8)

Some parents will need help to strengthen their ability to support their children to make positive choices. (ibid.)
}

Despite the significant reduction in many of the services provided for young people under the Coalition, Positive for Youth indicates that the government will continue to fund parental support including 'family champions' who will give 'one-to-one support and coaching for family members to help them overcome the problems they face’ (DfE, 2011, p.23). 
Explicit in much of the discussion of parenting and parent education within Positive for Youth and other government documents is the valorisation of a particular form of parenting. Indeed, Positive for Youth states that 'some parenting styles are better for children and young people's outcomes than others' (p.18) before going on to promote authoritative parenting. This is a parenting style in which the parent has high expectations of their child, but is also responsive to the child's needs, and employs supportive rather than punitive disciplinary measures (Baumrind, 1991). It is claimed by the Coalition that parents 'help their children by warm authoritative parenting, being actively involved in their learning and development, setting clear boundaries and holding high aspirations’ (p.13-14). In many ways, such pronouncements have much in common with New Labour policy, which placed considerable emphasis on parenting, in general, and the role of parents as supporters of young people's education, in particular. Indeed, Gewirtz (2001) has argued that Labour’s education programme was essentially 'an ambitious programme of resocialisation and re-education, which [had] as its ultimate aim the eradication of class differences by reconstructing and transforming working class parents into middle class ones’ (p.366). This, she suggests, was effected through: promoting active consumerism (for example, encouraging parents to become more discerning choosers when deciding on a school for their child); encouraging parental 'policing' of schools (for example, by closely monitoring the progress their child was making); and remaking parents as ‘home educators’ (by encouraging parents to be involved actively in their child’s homework). Similar arguments are made by Gillies (2005), who contends that the 'involved' parent is often, by virtue of circumstances, a middle class parent. This is because the time required to be actively involved in a child's learning is not, she suggests, available to all parents - particularly single parents and/or those who need to work long hours to support their family. Moreover, she argues that working class parents 
often feel devalued and misunderstood by teachers, which discourages them from frequent contact with their child’s school.

The parents of the ideal Coalition subject are not, however, identical to those valorised within Labour policy: greater emphasis has come to be placed on the importance of the nuclear family. While New Labour family policy has been criticised for doing little to shift the perception that women are the primary care-givers or to highlight the important connections between care-giving and gender equality, it did, nevertheless, recognise greater diversity than previously in family formation and parenting roles (Daly, 2010; Kilkey, 2006; Lewis, 2001). As Daly (2010) notes, ‘successive New Labour administrations had been sufficiently grounded in the realities of everyday life not to view family structure narrowly as the cereal packet family based on marriage' (p.441). Fostering and adoption by gay and lesbian couples were promoted (Logan and Sellick, 2007) and greater support was provided for women who wanted to work outside the home (Daly, 2010; Scourfield and Drakeford, 2002). In contrast, while a clear family policy is not articulated in Positive for Youth, implicit in the many references to parents are assumptions of a two-parent, heterosexual model: 'Parents' influence.....remains key. This includes both mothers and fathers’ (p.8). Moreover, the importance of the involvement of fathers in the lives of young people is emphasised frequently throughout the document, suggesting strongly that 'authoritative parenting' cannot be provided by a mother alone. This seems in line with the reassertion of more traditional family roles which, some commentators argue, are beginning to emerge as a result of Coalition policy (Annesley and Himmelweit, 2010; MacLeavy, 2011; Toynbee, 2012). It has also been argued that an emphasis on authoritative parenting is culturally non-inclusive, and has the effect of privileging white, middle class norms over those of other ethnic groups. Indeed, while there is evidence of a correlation between authoritative parenting and good 
academic performance for white young people, this is not the case for those from African and Asian groups (Darling, 1999; Garcia Coll et al, 1995).

\section{'Good characters'-in-the-making}

While the Coalition's emphasis on developing dutiful citizens shows strong links with the initiatives of the previous administration, its explicit discussion of the character of these citizens can be seen as more of a departure from the education and youth policies of the previous government. As will be suggested below, New Labour education and learning initiatives did have the effect of promoting particular character traits. They were not, however, ever stated as explicitly, or foregrounded within policy, to the extent which we see under the Coalition government. The significance of this aspect of its policy programme is signalled by the proportion of Positive for Youth that is devoted to it: 12 pages (out of the 96) are spent outlining the importance of 'Building Character and a Sense of Belonging' and the measures that are to be put in place to achieve this. In this section of the document, the nature of this desired character is made clear. Firstly, the ideal Coalition subject is independent and autonomous, and learns to be so through the school and/or college that he or she attends:

Schools and colleges play a vital part in developing character....They know how important it is to help young people develop the self-awareness, self-esteem and confidence to take decisions and seize control of their future learning and careers. (DfE, 2011, p.33)

Secondly, s/he relishes competition, develops her/himself through competing with others and is comfortable in quasi-military environments: 
Competitive sport provides a particular opportunity for young people to develop their character, resilience and team working skills. (p.36)

[Government funding of Cadet Forces in schools and colleges] represents a significant investment in the development of young people’s aspirations, character and leadership potential. (p.43)

Although this explicit emphasis on developing character is an apparent discontinuity with New Labour policy, the values emphasised above are, in many cases, not out of line with those that underpin - albeit implicitly - previous education policies. Indeed, Read et al. (2003) have argued that the way in which the 'ideal learner’ is often understood (by policymakers, but also by teachers, lecturers and students themselves) is as bold, individualistic and competitive. They suggest that this is a particularly masculinist construction, which privileges traits commonly associated with men, and disregards qualities which may be of equal (or greater) value for effective learning, but which are commonly seen as ‘feminine' (such as collaboration, dependence and mutual support) (see also Leathwood and O’Connell, 2009). Coalition policy can been seen as taking such masculinist constructions a step further, by explicitly promoting competitive sport and military engagement. It can also be seen as having a distinct ethnic bias: favouring the individualistic, competitive culture typical of many white middle class groups over the more collectivist approach of some other ethnic groups (Crozier, 2001; Phoenix and Husain, 2007).

As noted earlier in this article, the 'good character' of Coalition policy is also defined as being attuned to the market. This becomes clear when Positive for Youth outlines some of the 
mechanisms through which a desirable character can be developed. Despite the research which suggests that part-time work can often have a negative impact on academic achievement (Hunt et al., 2004; Metcalf, 2003), such employment is encouraged as a valuable means of learning ‘the habits of punctuality and persistence' (p.37), while 'Role models from the world of work...can be instrumental in helping young people...to be enterprising and entrepreneurial' (ibid.). Here, the distinct business-orientation of the ideal Coalition subject is again made clear.

Although such an explicit focus on improving the character of young people is a novel element of Coalition policy, its emphasis on developing for the future is in keeping with many other youth-focussed policies worldwide (Arnett, 2004; Wyn and White, 1997). Indeed, Lesko (2001) has argued that since the early twentieth century, the transitory nature of adolescence has been emphasised. Young people have been defined as ‘always “becoming”, waiting for the future to arrive' (p.131), a definition which has provoked, she maintains, 'endless watching, monitoring and evaluating' (p.111) on the part of adults, and a passivity on the part of young men and women as they are told that only the future matters, and that it is the end of the adolescent story that is key.

\section{A unitary group}

While Coalition policy has been keen to emphasise the importance of developing 'good character' as a worthwhile goal as young people move towards older adulthood, it has also sought to accentuate the distinctive nature of the adolescent period. This is attempted, within Positive for Youth, by drawing on evidence from neuroscience: 
New evidence is emerging that may help parents, carers and professionals understand what is happening as teenagers’ behaviour changes. This evidence comes from research on how the brain typically undergoes sharp and significant changes during the period from about 11 to 20 years. (DfE, 2011, p.8)

Research on how the brain develops now shows that in early adolescence young people may become more sensitive to rewards, but that it takes much longer before they develop their ability to control their impulses and make strategic decisions. (ibid.)

It is argued that such evidence may be of particular benefit to teachers (and other professionals) as well as parents.

This kind of analysis is notably absent from New Labour policy documents. However, it is in keeping with wider contemporary public debate. Indeed, in the UK over the past few years, there has been significant discussion - within academia, the media and policy circles - about the explanatory power offered by neuroscience (Royal Society, 2011). Possibly the most high-profile aspect of this debate has focussed on gender (McKie, 2010). In her book, Delusions of Gender (Fine, 2010), Cordelia Fine acknowledges the increasing frequency with which gender differences are explained by drawing on evidence purportedly from neuroscience - emphasising the 'hard wired' differences between male and female brains. She argues, however, that not only do such arguments validate the (gender-unequal) status quo but that they represent a misreading of the latest research within neuroscience and psychology. 
The neuroscience evidence with relation to differences between adolescents and older adults has not been subject to the same type of critique. Nevertheless, in its essentialising of youth, it does articulate with themes from the wider academic literature. Wyn and White (1997) have argued, for example, that by presenting young people as a unitary group, such policy texts have the effect of detracting attention from both commonalities across age groups and differences between young people. They go on to suggest that by assuming that age is the central process which categorises young people, insufficient weight is given to difference, process and change and, as a result, the wider social environment comes to be seen as less influential. Moreover, many scholars have contended that as a direct consequence of the 'destandardisation' of the life-course, in the UK and many other parts of the world, there is no longer a ‘normal situation’ for a person aged 18, 21 or 25 (Roberts, 1997). The neuroscience emphasis can also be seen as having much in common with biological and naturalistic models of youth, which have been used for over a century to construct and control young people (for example, Hall, 1903).

\section{Conclusion}

It is important to recognise that the impact of dominant political constructions of young people cannot simply be read off policy texts. As Braun et al. (2011) have shown in relation to their work in schools, policy is rarely transferred in a straightforward manner. Instead, it is 'enacted': translated, interpreted, challenged and sometimes resisted in different ways by different policy actors. Nevertheless, the dominant constructions of young people, identified in this article on the basis of its analysis of various policy documents, provide important evidence of the ways in which the UK’s Coalition's government understands its youth. Moreover, they help to illuminate the ideological underpinnings of the Coalition, feeding into 
the body of literature discussed at the beginning of the paper. Firstly, the ways in which young people are constructed in Positive for Youth and the education-specific policy documents suggest strong continuity with the neo-liberal orientation of previous governments (both New Labour and Conservative). This can be seen, in particular, through the emphasis placed on students (and, increasingly, their parents) as consumers of education, operating within a highly marketised system. As has been argued above, both new Labour and Coalition policies make explicit assumptions that 'student choice' is an effective means of increasing the quality of education, and that (despite research evidence to the contrary) young people have both the inclination and ability to act as rational consumers. Strong continuity is also evident in the business-focus of education policies under both new Labour and Coalition administrations. The interests of young people are seen as indistinguishable from those of business and assumptions are made that they can only benefit from increased private sector involvement in education, not least through the inculcation of business values, such as entrepreneurialism and competitiveness. Similarly, the Coalition's promotion of both individualism and a strong responsibility-based understanding of citizenship is also very much in line with its New Labour predecessor.

Nevertheless, the policy analysis has also demonstrated some areas of discontinuity in understandings of young people. This suggests that although the three main UK parties (Labour, the Conservatives and the Liberal Democrats) are often seen as competing for the ‘crowded middle ground' of UK politics, some significant shifts in policy have become evident under the Coalition government. With respect to young people, these appear to coalesce around a broadly socially conservative agenda. For example, the masculinist emphasis of the ideal Coalition subject, evident through the government's explicit promotion of military involvement and competitive sport, appears to be a clear departure from the more 
gender-neutral ‘active citizens’ which New Labour aimed to inculcate. This is not, however, to suggest that such constructions are new. Indeed, this particular emphasis has been a trend in citizenship education throughout the course of the $20^{\text {th }}$ century (Holt, 2008, Livingstone, 1943). The Coalition's emphasis on the importance of both mothers and fathers in parenting, and the implied problematisation of single mothering, is further evidence of social conservatism, and provides support for those who have suggested that Coalition policies, more generally, have tended to promote a regressive model of gender relations. Finally, the Coalition's recourse to neuroscience in attempting to understand the experience of youth can also be seen as a departure from New Labour policy. This departure has the effect of reproducing a biological and essentialist view of young people, rather than one that recognises the diversity of ways in which youth is experienced - by social class, gender, ethnicity and geographical location - and the role of wider society in shaping these experiences. While clearly youth policy should not be taken as necessarily representative of all social policy, this social conservatism does suggest that, in this area of policy at least, the influence of the historically social-liberal Liberal Democrats has been marginalised and that the constructions of young people within education policy are more heavily inflected by Conservative values.

\section{Acknowledgements}

I would like to thank the Centre for Chid and Youth Research at Brunel University (and particularly Nicola Madge) for inviting me to give a presentation on education under the UK Coalition government, which provided the basis for this paper. I am also grateful to the two anonymous referees for their very helpful comments on an earlier version of this paper. 


\section{References}

Annesley, C. and Himmelweit, S. (2010) The Impact on Women of the Coalition Spending Review 2010 UK Women’s Budget Group, London.

Arnett, J. (2004) Emerging Adulthood: the winding road from the late teens through the twenties New York, Oxford University Press.

Ball, S. (2003) Class Strategies and the Education Market. The Middle Classes and Educational Advantage London, RoutledgeFalmer.

Ball, S. (2007) Education plc. Understanding private sector participation in public sector education London, Routledge.

Ball, S., R. Bowe and S. Gewirtz (1997) 'Circuits of Schooling: a sociological exploration of parental choice of school in social-class contexts', in A. Halsey, H. Lauder, P. Brown and A. S. Wells (eds) Education: Culture, Economy, Society, pp. 409 - 421. Oxford: Oxford University Press.

Baumrind, D. (1991) The influence of parenting style on adolescent competence and substance use, Journal of Early Adolescence, 11, 1, 56-95.

Braun, A., Ball, S., Maguire, M. and Hoskins, K. (2011) Taking context seriously: towards explaining policy enactments in the secondary school, Discourse, 32, 4, 585-596. 
Brooks, R. (2007) Young people’s extra-curricular activities: critical social engagement - or 'something for the CV'? Journal of Social Policy, 36, 3, 417-434.

Brooks, R. (2009) Young people and UK citizenship education: a gender analysis, Young 17, 3, 307-326.

Brown, P. (1990) The 'third wave': education and the ideology of parentocracy, British Journal of Sociology of Education 11, 1, 65-85.

Chubb, J. and Moe, T. (1997) Politics, markets and the organisation of schools, in: Halsey, A., Lauder, H., Brown, P. and Wells, A. (eds) Education. Culture, Economy, Society Oxford, Oxford University Press, pp. 363-381.

Coffey, A. (2004) Reconceptualising Social Policy: Sociological Perspectives on Contemporary Social Policy Maidenhead, Open University Press.

Crozier, G. (2001) Excluded parents: the deracialisation of parental involvement, Race, Ethnicity and Education, 4, 4, 329-341.

Daly, M. (2010) Shifts in family policy in the UK under New Labour, Journal of European Social Policy, 20, 5, 433-43.

Darling, N. (1999) Parenting Style and its Correlates. ERIC Clearinghouse on Elementary and Early Childhood Education. 
Department for Business, Innovation and Skills (BIS) (2011) Higher Education: Students at the Heart of the System London, The Stationery Office.

Department for Education (2010) The Importance of Teaching London, The Stationery Office.

Department for Education (DfE) (2011) Positive for Youth. A new approach to crossgovernment policy for young people aged 13 to 19 London, The Stationery Office.

Department for Education and Skills (DfES) (2003) The Future of Higher Education London, The Stationery Office.

Department for Education and Skills (DfES) (2005a) 14-19 Education and Skills London, The Stationery Office.

Department for Education and Skills (DfES) (2005b) Higher Standards, Better Schools for All London, The Stationery Office.

Department for Education and Skills (DfES) (2005c) Youth Matters London, The Stationery Office.

Evans, E. (2011) Two heads are better than one? Assessing the implications of the Conservative-Liberal Democrat coalition for UK politics, Political Science, 63, 1, 45-60. 
Fine, C. (2010) Delusions of Gender: the real science behind sex differences London, Icon Books Ltd.

Foskett, N. and Hemsley-Brown, J. (2001) Choosing Futures London, RoutledgeFalmer.

Gamarnikow, E. and Green, A. (2000) Citizenship, education and social capital, in: Lawton, D., Cairns, J. and Gardner, R. (eds) Education for Citizenship London, Continuum.

Garcia Coll, C.T., Meyer, E.C. and Brillon, L. (1995) Ethnic and minority parents, in: Bornstein, M. (ed.) Handbook of Parenting: Volume II Mahwah, NJ, Lawrence Erlbaum Associates.

Garthwaite, K. (2011) ‘The language of shirkers and scroungers?’ Talking about illness, disability and Coalition welfare reform, Disability and Society, 26, 3, 369-372.

Gewirtz, S. (2001) Cloning the Blairs: New Labour's programme for the re-socialization of working class parents, Journal of Education Policy, 16, 4, 365-378.

Gillies, V. (2005) Raising the 'Meritocracy': parenting and the individualization of social class, Sociology, 39, 5, 835-853.

Hall, G. S. (1903) Adolescence, Its Psychology and Its Relations to Physiology, Anthropology, Sociology, Sex, Crime, Religion and Education New York, Appleton. 
Hall, T. and Williamson, H. (1999) Citizenship and Community Leicester, Youth Works Press.

Holt, J. (2008) Public School Literature, Civic Education and the Politics of Male Adolescence Aldershot, Ashgate.

Hunt, I, Lincoln, I and Walker, A. (2004) Term-time employment and academic attainment: evidence from a large-scale survey of undergraduates at Northumbria University, Journal of Further and Higher Education, 28, 1, 3-18.

Keihly, M.J. (2012) Contextualising the sexualisation of girls debate: innocence, experience and young female sexuality, Gender and Education, 24, 3, 255-268.

Kilkey, M. (2006) New Labour and Reconciling Work and Family Life: Making It Fathers’ Business? Social Policy and Society, 5, 2, 167-175.

Lauder, H. and Hughes, D. (1999) Trading in Futures. Why Markets in Education Don't Work Buckingham, Open University Press.

Leathwood, C. and O’Connell (2003) 'It's a struggle': the construction of the 'new student' in higher education, Journal of Education Policy, 18, 6, 597-615.

Lesko, N. (2001) Act Your Age! A cultural construction of adolescence New York, RoutledgeFalmer. 
Lewis, J. (2001) The End of Marriage?: Individualism and intimate relations Cheltenham, Edward Elgar.

Lister, R. with Smith, N., Middleton, S. and Cox, L. (2005) Young people and citizenship, in: Barry, M. (ed) Youth Policy and Social Inclusion Abingdon, Routledge.

Livingstone, R. (1943) Education for a World Adrift Cambridge University Press.

Logan, J. and Sellick, C. (2007) Lesbian and gay fostering and adoption in the United Kingdom: prejudice, progress and the challenges of the present, Social Work and Social Sciences Review, 13, 2, 35-47.

Lowndes, V. and Pratchett, L. (2012) Local governance under the Coalition Government: austerity, localism and the 'Big Society’, Local Government Studies, 38, 1, 21-40.

MacLeavy, J. (2011) A ‘new politics’ of austerity, workfare and gender? The UK coalition government's welfare reform proposals, Cambridge Journal of Regions, Economy and Society 2011, 1-13.

McKie, R. (2010) Male and female ability differences down to socialisation, not genetics, The Observer, $15^{\text {th }}$ August 2010, p.15.

Metcalf, H. (2003) Increasing Inequality in Higher Education: the role of term-time working, Oxford Review of Education, 29, 3, 315-329. 
Painter, C. (2012) The UK Coalition government: constructing public service reform narratives, Public Policy and Administration, 28, 1, 1-18.

Phoenix, A. and Husain, F. (2007) Parenting and Ethnicity York, Joseph Rowntree Foundation.

Pollock, A. and Price, A. (2011) The final frontier: the UK’s new Coalition government turns the English National Health Service over to the global health market, Health Sociology Review, 20, 294-305.

Quinn, T., Bara, J. and Bartle, J. (2011) The UK Coalition Agreement of 2010: Who Won? Journal of Elections, Public Opinions and Parties, 21, 2, 295-312.

Read, B., Archer, L. and Leathwood, C. (2003) Challenging Cultures? Student conceptions of 'belonging' and 'isolation’ at a post-1992 university, Studies in Higher Education, 28, 3, 262277.

Reay, D., David, M. and Ball, S. (2005) Degrees of Choice: social class, race and gender in higher education. London: Trentham Books.

Roberts, K. (1997) Structure and Agency: The New Youth Research Agenda, in: Bynner, J., Chisholm, L. and Furlong, A. (eds.) Youth, Citizenship and Social Change in a European Context Aldershot, Ashgate. 
Royal Society (2011) Brain Waves Module 1: Neuroscience, Society and Policy (RS Policy

Document 1/11) London, Royal Society.

Scourfield, J. and Drakeford, M. (2002) New Labour and the 'Problem of Men', Critical Social Policy, 22, 4, 615-636.

Shepherd, J. (2011) Don’t scrap citizenship lessons, teachers plead, The Guardian, 20 January 2011.

Taylor-Gooby, P. (2012) Root and branch restructuring to achieve major cuts: the social policy programme of the 2010 UK Coalition government, Social Policy and Administration, $46,1,61-82$.

Toynbee, P. (2012) Calm Down Dears? Why it's a bad time to be a British woman, The Guardian, $8^{\text {th }}$ March, p.1.

Williams, J. (2011) Constructing consumption: what media representations reveal about today’s students, in: Molesworth, M., Scullion, R. and Nixon, E. (eds) The Marketisation of Higher Education and the Student as Consumer London, Routledge.

Wyn, J. and White, R. (1997) Rethinking Youth London, Sage.

\footnotetext{
${ }^{\mathrm{i}}$ The exception to this is the work that has explored policy measures to combat what is perceived to be the 'sexualisation of childhood' (Keihly, 2012).

ii 'Free schools' are independent schools established by parents or community groups, which are funded directly by the state.

${ }^{\text {iii }}$ Academies are independent schools, funded directly by the state.
} 


\footnotetext{
${ }^{\text {iv }}$ Although the focus of the analysis was primarily on the extent to which Coalition policies represented continuity or change with respect to the previous (Labour) administration, it is important to recognise that there are also important continuities between Labour education policies and those of previous Conservative administrations (from Margaret Thatcher's 1979 government onwards).

${ }^{\mathrm{v}}$ This was originally set at AAB but in May 2012 was changed to ABB.
} 